\title{
Criminal Liability of Patient's Family Who Refused Medical Action in the Case of Covid-19
}

\author{
Sri Inggriani ${ }^{1}$, Faisal Santiago ${ }^{2}$ \\ Universitas Borobudur Jakarta, Jl. Raya Kalimalang No. 1, Jakarta Timur, Indonesia ${ }^{1,2}$ \\ \{riunboro@gmail.com¹, faisalsantiago@borobudur.ac.id²\}
}

\begin{abstract}
When a patient's condition is in an emergency and is exposed to a disease that requires special treatment such as isolation, prompt and precise medical action is needed. However, the patient's family should be the representative of the patient to obtain consent, but the patient's family refused the medical treatment so that informed consent was not implemented in the therapeutic agreement. The problem in this research is what is the criminal liability for the families of patients who refuse medical action in the case of Covid-19? The research method used is normative juridical using secondary data and analyzed using qualitative methods. The results of the study show that the criminal responsibility for the family of patients who refuse medical action in the Covid-19 case is imprisonment and fines. These sanctions are not regulated in Law Number 29 of 2004 concerning Medical Practice but are strictly regulated in Article 14 of Law Number 4 of 1984 concerning Infectious Disease Outbreaks and Article 93 of Law Number 6 of 2018 concerning Health Quarantine. Although the act of refusal to take a medical action by a parent or family against a member of his family is not necessarily a crime, however, criminal law enforcement can be carried out against this act of refusal and this needs to be proven again through a legal process in court.
\end{abstract}

Keywords: Criminal Liability; Doctor's Action; Covid-19

\section{Introduction}

Medical practice in Indonesia is regulated in Law Number 29 of 2004 concerning Medical Practice which aims to provide legal protection for doctors in carrying out their work and also for patients who use the services of doctors. Based on Article 50 of Law Number 29 of 2004 concerning Medical Practice, doctors are entitled to legal protection from any lawsuits against them. Based on these provisions, as long as doctors perform their work under professional standards and standard operating procedures, doctors cannot be prosecuted for administrative, civil, or criminal charges. In the effort to take the medical action he will do; the doctor will first ask for the patient's approval for medical action through a communication process called informed consent.

Informed consent is the consent given by a patient and/or his family as basic information and an explanation of the medical actions to be taken against the patient [1]. The legal basis for implementing informed consent is in Article 45 paragraph (3) of Law Number 29 of 2004 
concerning Medical Practice which contains information or explanations in the form of diagnosis and procedures for medical action, the purpose of medical action taken, other alternative actions and risks, risks. and possible complications and the prognosis of the action taken.

A doctor may not impose his will on a patient, even if it is according to his knowledge or for the benefit of the patient himself. Doctors must respect whatever choice of these patients because what distinguishes doctors from general criminal offenses is informed consent [2]. If informed consent has occurred, then the rights and obligations of the doctor and patient will arise. This is where the legal relationship between doctors and patients arises because of medical factors which in turn give birth to an agreement known as a therapeutic agreement.

A therapeutic agreement is a treatment agreement because one party (patient) wishes to recover and the other party (doctor) wishes to treat the patient and seek the patient's recovery. The agreement was born based on an agreement between the two parties without any mistake, coercion or fraud, and acts as law for the parties and must be implemented based on good faith [3]. Therapeutic agreements performed using informed consent involve medical personnel (doctors) and patients. In carrying out the therapeutic agreement, both parties must be responsible and carry out their respective obligations. But on the one hand, both parties are also granted rights by law, so that both parties also get legal protection [4].

In the case of an emergency such as a disaster or epidemic, the doctor can take medical action without the need to obtain consent from the patient or patient's family to save the patient's life. This is as regulated in Article 4 Permenkes Number 290 / MENKES / PER / III / 2008 concerning Approval of Medical Action that in an emergency, informed consent is not required. Based on this, the position of doctors and patients in informed consent is not equal. This is due to therapeutic transactions that are born under the order of law, namely Article 51 letter $d$ of Law Number 29 of 2004 concerning Medical Practice which states that doctors in carrying out medical practices must provide emergency assistance on a humanitarian basis unless they are certain that there are people. others who are in charge and able to do so.

Problems arise when the patient's condition is in an emergency and is exposed to a disease that requires special treatment such as isolation. However, the patient's family should be the representative of the patient to obtain consent, but the patient's family refused the medical treatment so that informed consent was not implemented in the therapeutic agreement. Whereas informed consent in a therapeutic agreement is an obligation for doctors to perform medical actions under the mandate of Law Number 29 of 2004 concerning Medical Practice.

In Article 52 letter d Law Number 29 of 2004 concerning Medical Practice in conjunction with Article 16 Permenkes Number 290 / MENKES / PER / III / 2008 concerning Approval of Medical Action regulates the rights of patients and their families to refuse medical treatment. Based on the foregoing, if the patient exercises his right to refuse a medical action in which the patient has received information following the applicable procedure, then all consequences of the refusal have been understood and all consequences are the responsibility of the patient himself.

The reasons for the family refusing medical treatment by doctors were due to two factors, that is psychological and economic factors. The psychological reason referred to is that there is a feeling of pity for the patient's condition or the patient no longer believes in the benefits of certain treatments for curing his illness. The patient has concluded that treated or untreated, the results are the same, therefore refusing treatment is better. The economic reason is that the patient wants to get treatment for himself, but because he does not have sufficient funds to pay for the treatment, he stops the treatment [5]. This is as happened in the case of family refusal of corona positive patients to be isolated in the hospital. 
In this case, the number of residents infected with Covid-19 in the Pamekasan Regency continues to increase. Three more people tested positive. One of them is an immigrant from South Sulawesi, who just returned a few weeks ago to his village. This patient reportedly worked in Makassar, South Sulawesi, as a dentist. Initially, the person concerned was monitored by Pegantenan Health Center officers [6].

The sample of the swab in question was taken on April 17, 2020 and Wednesday, April 29, 2020, the results were positive. However, the Pamekasan Regency Covid-19 Task Force is still negotiating with his family so that he wants to be isolated in the hospital. This is because the family refused to be isolated in the hospital. The same case also happened to a patient at the Regional General Hospital (RSUD) Arifin Achmad, Riau Province.

In that case, one of the eight people who tested positive for multi-drug resistant tuberculosis (MDR-TB) in Riau Province refused to undergo treatment at a local hospital out of frustration. The reason is that he is a driver who has to support his family, so there is no time for regular medical treatment [7].

To get optimal healing, MDR-TB sufferers must undergo regular treatment every day through the guidance of specialized medical personnel. In addition to having to take medication regularly every day, these patients or sufferers must also control their physical condition regularly, because this type of disease is very dangerous. Incorrect treatment or even slow treatment can cause death even in a short time.

The absence of medical action by a doctor, when undesirable things occur, the doctor's position to be the party to be blamed becomes very large on the pretext of negligence as regulated in Article 359 of the Criminal Code with the threat of punishment is imprisonment for 5 (five) years. or in Article 531 of the Criminal Code which can be imposed on a doctor or on a patient or patient's family whose punishment is imprisonment for 3 (three) months. Based on the above background, the problem in this study is how the family criminal responsibility for patients who refuse medical action in the case of Covid-19?

\section{Research Method}

\subsection{Research Category}

This research is normative juridical research because the target of this research is a law or normative principles in the form of legal principles and legal systems [8]. Normative research in this study is a study that describes or describes in detail, systematically, thoroughly, and deeply the rationale for the family criminal responsibility of patients who refuse medical action in the case of Covid-19.

\subsection{Research Nature}

This research is descriptive because it describes the prevailing laws and regulations and is associated with legal theories in their implementation practices relating to the problems to be studied.

\subsection{Data Analysis}

The data obtained will be analyzed using qualitative analysis. 


\section{Result and Discussion}

Hospital [9] as a health service institution is described in Law Number 44 of 2009 concerning Hospitals, where Article 1 paragraph (1) reads:

"A hospital is a health service institution that provides complete individual health services that provide inpatient, outpatient and emergency services".

Based on this, it can be interpreted that the hospital is a health service institution that functions to provide and organize health efforts that are healing and restoring patients and patient safety. Health services provided by the hospital to patients can also be seen as services provided between business actors (hospitals) and patients (consumers) [10].

In the preamble of Law Number 44 of 2009 concerning Hospitals, it states that health services are the right of everyone guaranteed in the 1945 Constitution of the Republic of Indonesia which must be realized by efforts to improve the highest public health status. Hospital is a health service institution for the community with its characteristics that are influenced by the development of health science, technological advances, and the socioeconomic life of the community which must continue to be able to improve quality and affordable services for the community to attain the highest health degree.

To improve the quality and coverage of hospital services and regulate the rights and obligations of the community in obtaining health services, it is necessary to regulate hospitals by law. The regulation regarding hospitals is not sufficient enough to be used as a legal basis for the operation of hospitals as health service institutions for the community. Based on these considerations and to provide legal certainty for the community and hospitals, it is necessary to form a Law on Hospitals.

Hospitals in carrying out health service activities require adequate health personnel as one of the requirements for their management resources. In Article 12 of Law Number 44 of 2009, it is stated that: (1) The requirements for human resources as referred to in Article 7 paragraph (1), namely the Hospital must have permanent staff which includes medical personnel and medical support, nursing personnel, pharmaceutical personnel, Hospital management personnel, and non-health personnel. (2) The number and type of human resources as referred to in paragraph (1) must be following the type and classification of the Hospital. (3) Hospitals must have data on personnel who carry out practices or jobs in the operation of the Hospital. (4) Hospitals can employ temporary staff and consultants according to their needs and abilities by the provisions of laws and regulations. Medical personnel includes doctors and dentists as well as specialist doctors and specialist dentists.

Health services provided by doctors after the issuance of Law Number 29 of 2004 concerning Medical Practices encourage everyone who works in the health sector to follow the rules listed in it. Law Number 29 of 2004 concerning Medical Practice, Law Number 36 of 2009 concerning Health, and Law Number 44 of 2009 concerning Hospitals are referenced in legal protection for health workers, especially doctors and dentists in carrying out health services to patients in particular and society in general.

Article 3 of Law Number 29 of 2004 concerning Medical Practice regulates the objectives of medical practice so that its implementation is protected by applicable law. Besides, this law aims to provide legal certainty to the public, doctors, and dentists. Doctors and dentists are legally protected in providing health efforts based on the provisions of Article 23 of Law Number 36 of 2009 concerning Health, (1) that health workers are authorized to carry out health efforts, (2) the authority to provide health services as referred to in paragraph (1) 
carried out by their expertise, (3) In providing health services, health workers are required to have a permit from the government.

Health effort [11] is any activity and or series of activities performed in a cohesive, integrated and sustainable manner to maintain and increase the degree of public health in the form of disease prevention, health improvement, disease treatment, and health restoration by the government and or the community. Health efforts are carried out by health workers, while health services consist of five types of services, namely promotional health services, preventive health services, curative health services, rehabilitative health services, and traditional health services.

The demand for excellent health services under Law Number 29 of 2004 concerning Medical Practice, which states the rights and obligations of actors in the health sector, of course, cannot be separated from these binding legal rules. The implementation of health efforts depends on the availability of health resources in the form of personnel, facilities, and infrastructure in sufficient quantity and quality. Health services as part of the main hospital activities place doctors and nurses as health workers who are closest to patients in managing the disease. There are several relationships in these health service efforts, namely the relationship between hospitals and doctors; nurse with the patient; the relationship between doctors and nurses and patients; and the relationship between nurse and patient.

Based on Article 1 point 2 of Law Number 29 of 2004 concerning Medical Practice, it states that doctors and dentists are doctors, specialists, dentists, and specialist dentists who have graduated from medical or dentistry education both at home and abroad who are recognized by the government Republic of Indonesia under statutory regulations. The medical profession is noble and noble, besides that, there are 6 (six) basic characteristics, namely divinity, purity of intention, nobility, humility, the sincerity of work, scientific integrity, and social [12]. Therefore, it is very natural that the presence of a doctor is expected to provide good health services.

Medical practice is a series of activities performed by doctors and dentists on patients in carrying out health efforts [13]. Doctors in carrying out their duties, namely striving for one's health as described in Article 1 number 1 of Law Number 29 of 2004 concerning Medical Practice, of course, have their own rules which serve as guidelines in their duties. One of these guidelines is about informed consent.

Informed consent is the consent given by a patient and/or his family based on the information and an explanation of the medical actions that will be performed on the patient [14]. The legal basis for implementing informed consent is in Article 45 paragraph (3) of Law Number 29 of 2004 concerning Medical Practice which contains information or explanations in the form of diagnosis and procedures for medical action, the purpose of medical action taken, other alternative actions and risks, risks. and possible complications and the prognosis of the action taken.

A doctor may not impose his will on a patient, even if it is according to his knowledge or for the benefit of the patient himself. Doctors must respect whatever choice of these patients because what distinguishes doctors from general criminal offenses is informed consent [15]. This Medical Action Approval is related to the doctor's obligation to provide information to patients and the obligation to perform medical actions according to the standards of the medical profession. A new informed consent is validly given by the patient if it meets at least 3 (three) elements as follows:

a. Sufficient information disclosure is provided by the doctor;

b. The patient's competence in giving consent;

c. Volunteerism (without coercion or pressure) in approving. 
In the law of health, there are two forms of informed consent, namely:

\section{a) Implied Consent (Deemed Given)}

Generally, implied consent is given in normal circumstances, meaning that the doctor obtains the consent of the medical action from the signal given or carried out by the patient. Likewise with emergency cases, while doctors require immediate action while the patient is unable to give consent and his family is not present, in this case, the doctor can make the best medical action according to the doctor.

This is under the principle of father knows the best, which means that doctors have a role like parents towards their patients [16]. The patient fully trusts the doctor to take medical action against him. This kind of relationship is active-passive and has a vertical pattern which makes the position of the doctor and patient unequal and makes the patient have to accept all doctor's decisions and actions by not contributing anything to the medical services he receives. Therefore, there is no communication interaction whatsoever regarding the medical action to be performed [17].

\section{b) Expressed Consent (Affirmed)}

Medical consent (informed consent) in the form of expressed consent (expressed), can be expressed orally or in writing. In medical procedures that are invasive and contain risks, doctors should obtain written approval, or what is commonly known in hospitals as a license to operate. Based on this, in an emergency, informed consent remains the most important thing even though it has the lowest priority. The most important priority is to save the patient's life, although informed consent is important, it should not be a barrier or barrier to the implementation of emergency care. This is following Article 4 of the Minister of Health Regulation Number 290 / MENKES / PER / III / 2008 concerning Approval of Medical Action that in an emergency, informed consent is not required.

Based on this, the position of doctors and patients in informed consent is not equal. This is due to therapeutic transactions that are born under the order of law, namely Article 51 letter $\mathrm{d}$ of Law Number 29 of 2004 concerning Medical Practice which states that doctors in carrying out medical practices must provide emergency assistance on a humanitarian basis unless they are certain that there are people. others who are in charge and able to do so. However, in terms of informed consent in the form of expressed consent, the doctor's position on informed consent is equal to that of the patient. Therefore, informed consent in the form of expressed consent is required to fulfill all elements of the validity of the agreement stipulated in Article 1320 of the Civil Code.

The author believes that doctors are obliged to carry out informed consent, none other than in the framework of providing legal protection for doctors and patients for their medical actions. If a doctor has taken a medical procedure under Standard Operating Procedures, the doctor is entitled to protection as regulated in Article 50 letter $a$ of Law Number 29 of 2004 concerning Medical Practice which states that doctors in carrying out medical practice have the right to legal protection while carrying out their duties. under professional standards and standard operating procedures.

In some cases, as the author explains in the background, some parents or families refuse to take medical action against their families. There are several reasons put forward by families or parents who refuse to take medical action, such as two factors, namely psychological and economic factors. The psychological reason referred to is that there is a feeling of pity for the 
patient's condition or the patient no longer believes in the benefits of certain treatments for curing his illness. The patient has concluded that treated or untreated, the results are the same, therefore refusing treatment is better. The economic reason is that the patient wants to get treatment for himself, but because he does not have sufficient funds to pay for the treatment, he stops the treatment [18].

Problems arise when there is a refusal to take medical action, making the position of doctors and hospitals vulnerable to being sued, so can the family or parents who refuse to take medical action against patients who are in an emergency can be punished? The author believes, as the author has explained above, that the legal basis for doctors carrying out medical actions is the existence of informed consent as regulated in Article 45 paragraph (3) of Law Number 29 of 2004 concerning Medical Practice and Permenkes Number $290 /$ MENKES / PER / III / 2008 concerning Approval of Medical Action.

Regulations for criminal sanctions against the refusal of the patient's family or parents to take medical action are not regulated in Law Number 29 of 2004 concerning Medical Practice or Permenkes Number 290 / MENKES / PER / III / 2008 concerning Approval of Medical Action. This is because the patient and/or his immediate family can refuse any medical action that will be performed, after the patient and/or his immediate family receive an explanation regarding the medical procedure. Refusal to take medical action must be done in writing. However, it should also be noted that the result of refusal to take this medical procedure is that any consequences that occur will be the responsibility of the patient, or the responsibility of the patient's family for an incompetent patient.

Although in Law Number 29 of 2004 concerning Medical Practice as well as in Permenkes Number 290 / MENKES / PER / III / 2008 concerning Approval of Medical Actions it does not regulate criminal sanctions for refusal of the patient's family or parents for medical treatment, however Thus, when referring to other laws and regulations, several provisions are governing criminal sanctions against the refusal of the patient's family or parents to take medical action in the case of Covid-19.

Currently, Indonesia is experiencing a Covid-19 pandemic as the author has explained in the background. President Joko Widodo officially designated COVID-19 as a national disaster. This determination was stated in the Presidential Decree (Keppres) of the Republic of Indonesia Number 12 of 2020 concerning the Designation of Non-Natural Disaster for the Spread of Corona Virus Disease 2019 (COVID-19) as a National Disaster.

Based on Article 1 point 3 of Law Number 24 of 2007 concerning Disaster Management, it regulates that non-natural disasters are disasters caused by non-natural events or series of events, including technological failure, modernization failure, epidemics, and disease outbreaks. In Article 1 number 1 of Law Number 4 of 1984 concerning Communicable Disease Outbreaks, it is required that:

"An epidemic of an infectious disease hereinafter referred to as an epidemic, is an outbreak of an infectious disease in the community in which the number of sufferers has increased significantly more than the usual condition at a certain time and in a certain area and can cause disaster."

Efforts to control epidemics such as Covid-19 are regulated in Article 5 paragraph (1) of Law Number 4 of 1984 concerning Contagious Disease Outbreaks including:

1. Epidemiological investigation;

2. Examination, treatment, care and isolation of patients, including quarantine measures;

3. Prevention and immunization;

4. Elimination of disease causes;

5. Handling of bodies due to the plague; 
6. Outreach to the community;

7. Other countermeasures.

Based on these provisions, one of the efforts to overcome the Covid-19 disaster is to carry out quarantine. Based on Article 1 number 6 of Law Number 6 of 2018 concerning Health Quarantine, it regulates that:

"Quarantine is the limitation of activities and/or separation of a person who is exposed to an infectious disease as stipulated in the laws and regulations even though he has not shown any symptoms or is in the incubation period, and/or separates containers, Transport Equipment, or any goods suspected of being contaminated from people and/or Items that contain disease-causing or other sources of contamination to prevent possible spread to nearby people and/or goods. "

The purpose of holding quarantine is not only aimed at healing but at the same time to prevent the sufferer from becoming a source of disease transmission and spreading to the community. Meanwhile, actions against healthy people are carried out so that they do not become sick and disease carriers. In some cases, as the author explains in the background, there has been a refusal from the family to take medical action against family members who are positive for Covid-19. Against this refusal, there is a criminal sanction that can be addressed to the patient's family as regulated in Article 14 of Law Number 4 of 1984 concerning Infectious Disease Outbreaks which stipulate that:

a. Anyone who deliberately obstructs the implementation of epidemic control as provided for in this Law shall be punished with imprisonment of up to 1 (one) year and/or a maximum fine of Rp. 1,000,000 (one million rupiah).

b. Any person who due to his / her negligence obstructs the implementation of the epidemic control as regulated in this Law shall be punished with imprisonment for a maximum of 6 (six) months and/or a maximum fine of Rp. 500,000 (five hundred thousand rupiahs).

c. The criminal acts as meant in paragraph (1) are crimes and the criminal acts as meant in paragraph (2) are violations.

Other provisions are also regulated in Article 93 of Law Number 6 the Year 2018 concerning Health Quarantine, which stipulates that:

"Every person who does not comply with the implementation of Health Quarantine as referred to in Article 9 paragraph (1) and/or obstructs the implementation of Health Quarantine to cause a Public Health Emergency will be sentenced to imprisonment of 1 (one) year and/or a maximum fine. Rp 100,000,000.00 (one hundred million rupiah). "

Based on this, the act of refusing a medical action committed by a parent or family against a family member is not necessarily a criminal offense, even though the refusal action can be criminalized and this needs to be proven again through a legal process in the court.

\section{Conclusion}

The criminal responsibility for the family of patients who refuse medical action in the Covid-19 case is imprisonment and fines. These sanctions are not regulated in Law Number 29 of 2004 concerning Medical Practice but are strictly regulated in Article 14 of Law Number 4 of 1984 concerning Infectious Disease Outbreaks and Article 93 of Law Number 6 of 2018 concerning Health Quarantine. Although the act of refusal to take a medical action by a parent or family against a family member is not necessarily a criminal act, however, criminal law enforcement can be carried out against such refusal and this needs to be proven again through a legal process in court. 


\section{References}

[1] Siswati, Sri.: Etika dan Hukum Kesehatan. Raja Grafindo Persada, Jakarta (2013).

[2] Ratman, Desriza.: Aspek Hukum Informed Consent dan Rekam Medis Dalam Transaksi Terapeutik. Keni Media, Bandung (2013).

[3] Ohoiwutun, Y.A. Triana.: Bunga Rampai Hukum Kedokteran. Bayumedia, Malang (2007).

[4] Ohoiwutun, Y.A. Triana.: Bunga Rampai Hukum Kedokteran. Bayumedia, Malang (2007).

[5] Zulhasmar, Eric.: Implikasi Hukum Penolakan Tindakan Medik. Lex Jurnalica, Vol.5 No. 2. (April 2008).

[6] Keluarga Menolak Pasien Positif Corona Diisolas Pemerintah Turun Tangan. Artikel. (2020) Retrieved from https://regional.kompas.com/read/2020/04/30/16592631/keluarga-menolak-pasien positif-corona-diisolasi-pemerintah-turun-tangan.

[7] Frustasi Tak Kunjung Sembuh Pasien Menolak Diobati. Artikel. (2020) Retrieved from https://nasional.republika.co.id/berita/nasional/daerah/mz4bii/frustrasi-tak-kunjungsembuh-pasien-menolak-diobati

[8] Soekanto, Soerjono dan Sri Mamuji.: Penelitian Hukum Normatif-Suatu Tinjauan Singkat. Rajawali Press, Jakarta (2007).

[9] Jacobalis, Samsi: Kumpulan Tulisan terpilih Tentang Rumah Sakit Indonesia dalam Dinamika Sejarah, Transformasi, Globalisasi dan Krisis Nasional. Yayasan Penerbitan IDI, Jakarta (2008).

[10] Bastian, Indra.: Penyelesaian Sengketa Kesehatan. Salemba Medika, Jakarta (2011).

[11] Dumilah.: Kebijakan Kesehatan Prinsip dan Praktik. Raja Grafindo Persada, Jakarta (2015).

[12] Hanafiah, Jusuf.: Etika Kedokteran dan Hukum Kesehatan. EGC, Jakarta (2008).

[13] Undang-Undang Nomor 29 Tahun 2004 tentang Praktek Kedokteran.

[14] Siswati, Sri.: Etika dan Hukum Kesehatan. Raja Grafindo Persada, Jakarta (2013).

[15] Ratman, Desriza:: Aspek Hukum Informed Consent dan Rekam Medis Dalam Transaksi Terapeutik. Keni Media, Bandung (2013).

[16] Koeswadji, Hermin Hadiati.: Hukum Kedokteran. Citra Aditya Bakti, Bandung (1998).

[17] Prasetyo, Pradhipta Priyo.: Perlindungan Hukum Bagi Dokter Terhadap Informed Consent Dalam Perjanjian Terapeutik Studi Kasus Putusan Peninjauan Kembali Mahkamah Agung Nomor 79 PK/PID/2013. Tesis. Pascasarjana Universitas Gadjah Mada, Yogyakarta (2014).

[18] Zulhasmar, Eric.: Implikasi Hukum Penolakan Tindakan Medik. Lex Jurnalica, Vol.5 No. 2. (April 2008). 